\title{
LIFE HISTORIES OF CUBAN LEPIDOPTERA
}

\author{
By V. G. Dethier \\ John Carroll University, \\ Cleveland, Ohio
}

\section{INTRODUCTION}

The life histories described in this paper are, for the most part, those of insects whose immature stages have hitherto been unknown. Also included are accounts which supplement the descriptions of species treated by earlier authors. Even the most meager notes are included here because it is felt that every fact however brief aids in the further study of a life history. For a list of previous studies of some of these species the reader is referred to Davenport and Dethier (1937). Color descriptions are based upon a comparison with Ridgway's (1920) color charts.

This work was made possible by a Harvard University Fellowship which enabled the author to pursue research at the Atkins Institution of the Arnold Arboretum in Soledad, Cuba.

Egg

Calisto herophile Hbn.

Ivory yellow to white when laid. Nearly spherical. Covered with a fine raised reticulation forming minute polygonal areas. A day or more after being laid the egg develops tawny-olive markings (Figs. 5, 6, and 8).

First Instar

Head height $.6 \mathrm{~mm}$; head width $.7 \mathrm{~mm}$. General color of head bronze. Entire surface covered with a fine irregular dark brown raised reticulation. The background of the frontal areas is lighter than the rest of the head. Ocelli white. Edge of clypeus and mandibles dark brown. There are a few colorless tapering hairs and characteristic protuberances (Fig. 3). Body length 2 to $4 \mathrm{~mm}$. Newly hatched 
larva ivory yellow striped with ochraceous-buff (Fig. 11). Anterior portion of body light ochraceous-salmon. After eating the anterior portion of the body becomes greenish. The mid-dorsal, para-dorsal, and suprastigmatal lines become brownish. The stigmatal and infrastigmatal lines become dark greenish. The background of the body is now whitish green. On segments one and two at the para-dorsal line there is a black splotch slightly more anterior in position than the dark brown spiracle. A few long colorless hairs with bulbous tips are scattered over the body. Those on the posterior segments are the longest. Those on the prothorax are longer than the ones on the remaining thoracic segments.

\section{Second Instar}

Head height .6 mm.; head width $.7 \mathrm{~mm}$. General color very light brown to gray. Surface granular. Three rather indistinct streaks composed of rather minute gray to fuscous dots extend over the head. They merge to a varying degree (Fig. 1). On the posterior part of the head in particular these three streaks are more or less continuations of the dorsal longitudinal lines of the body. The background is the color of parchment. There are numerous short colorless hairs arising from conspicuous black tubercles. Prominent on the sides of the head are two irregular black protuberances. Body length 4 to $5.5 \mathrm{~mm}$. The wide dorsal, the thin paradorsal, and the wide suprastigmatal lines are sayal brown. On either side of the para-dorsals are irregularly marked light brown bands. The black splotch in the para-dorsal is largest on segment three. Between the suprastigmatal and stigmatal lines is a thin band of plumbago blue. The stigmatal line is outlined with darker brown and the infrastigmatal line is plumbago blue. Spiracles dark brown. Ventum dead grass yellow. Many short colorless tapering hairs cover the body.

Third Instar

Head height $.9 \mathrm{~mm}$; head width $1.0 \mathrm{~mm}$. Head differs but little from previous instar. It is lighter due to the smaller extent of dark streaks. Body 6 to $8.5 \mathrm{~mm}$. long. Bands on body more distinct. On each segment in addition 
to the para-dorsal and suprastigmatal black splotches there is now a black spot on the border of the mid-dorsal line. Further changes in the body markings are shown in Fig. 9. The substigmatal line is white and very broad.

\section{Fourth Instar}

Head height $1.25 \mathrm{~mm}$; head width $1.25 \mathrm{~mm}$. The only black now remaining on the head is an indistinct transverse band between the two prominent knobs, a short band extending posteriorly from each knob to the foramen magnum, and a slight black area near the ocelli. Body length $9 \mathrm{~mm}$. Not much change. Markings intensified.

Eggs were laid May 6 and 7 and hatched May 13 and 17 six to eleven days having elapsed. The first instar required seven days all moults having been completed by May 24 . The second instar occupied from twelve to fourteen days with moults on May 29 and June 2. The third instar was completed in eight days and the fourth in ten. Many different species of grass served as food plants, but lawn grass was preferred.

Egg

Metamorpha stelenes insularis (Holland)

Dark pea green. Height $1.2 \mathrm{~mm}$. Greatest diameter .9 $\mathrm{mm}$. There are fourteen raised white longitudinal ribs. At the apex of the egg the ribs present a few serrations when viewed in profile. Here also they join to form a stem-like projection on the summit of which is located the micropyle. The base of the egg, the surface applied to the food plant, is perfectly flat. It is divided into faint minute polygonal areas.

First Instar

Head height $.5 \mathrm{~mm}$; head width $.75 \mathrm{~mm}$. Smooth shiny black with a few long black hairs. These are in part microscopically serrate. Body $3 \mathrm{~mm}$. long. Clear transparent burnt yellow. Green from gut shows through. Few long black serrate hairs arising from very large tubercles. Spiracles brown.

Second Instar

Head height $.9 \mathrm{~mm}$; head width $1.0 \mathrm{~mm}$. Shiny black. 
Bears two prominent dorsal spines. Each spine $1.4 \mathrm{~mm}$. long. Club-shaped and bears long and short black hairs (Fig. 10). The long hairs are serrate. Body $6 \mathrm{~mm}$. long. Shiny transparent, diamine brown. Anal segment frequently yellowish. Body later becomes dark shiny Danube green except for the last two segments. There are no conspicuous spines on segment one. Segments two and three have but one spine in the pleural region in addition to paradorsal spines. The mid-dorsal spines are lacking. The remaining segments bear mid-dorsal, para-dorsal, suprastigmatal, and infrastigmatal spines. The anal segment bears two mid-dorsal spines. All these spines are black.

\section{Third Instar}

Head height $1.3 \mathrm{~mm}$; head width $1.5 \mathrm{~mm}$. Shiny black. Club-shaped dorsal spines $3 \mathrm{~mm}$. long. Hairs longer and more numerous. Body length 10 to $13 \mathrm{~mm}$. Body exceedingly dark chocolate to shiny black. Para-dorsal row of spines possesses large orange, fleshy bases (Fig. 2). Otherwise no change from preceding instar.

\section{Fourth Instar}

Head height $1.8 \mathrm{~mm}$; head width $2.0 \mathrm{~mm}$. Dorsal spines now $6 \mathrm{~mm}$. long. Body length 15 to $19 \mathrm{~mm}$. No noticeable change from previous instar.

Eggs laid singly on the underside of leaves of Blechum blechum on May 4 emerged four days later on May 8. The butterfly oviposited only on seedlings. The young larvæ ate the entire egg shell and for the duration of the first instar ate the epidermal hairs of the food plant. The first instar was of three days' duration with moulting occurring May 11. The second instar required three days and the third, four days.

\section{Egg}

\section{Anteos clorinde nivifera Fruhstorfer}

Color varies from very light greenish to yellowish. It may be white. Length $1.5 \mathrm{~mm}$. Greatest diameter .45 $\mathrm{mm}$. There are on the average fourteen longitudinal ribs. Only every other one extends to the tip of the egg. All are joined by many parallel cross striations which at the apex of the 
egg form the micropyle rosette. The end of the egg bearing the micropyle is acute as compared with the base.

First Instar

Head height .4 mm.; head width $.25 \mathrm{~mm}$. Head entirely colorless and transparent except for the black pigment of the ocelli. Bears a few long transparent hairs. Surface microscopically rugose. Body $4 \mathrm{~mm}$. long. Light greenish yellow. Green from gut clearly visible. Numerous long colorless hairs. Body surface microscopically rugose.

Second Instar

Head height $.7 \mathrm{~mm}$.; head width $.5 \mathrm{~mm}$. Body length 6 $\mathrm{mm}$. Very similar to previous instar. Surface of head and body rougher. Hairs shorter and more numerous. Color same. Some individuals darker yellow.

Third Instar

Head height $1.0 \mathrm{~mm}$; head width $.8 \mathrm{~mm}$. Body 9 to 11 $\mathrm{mm}$. long. Very similar to preceding instar. Hairs on head and body still shorter and more numerous.

Fourth Instar

Head height $2.0 \mathrm{~mm}$; head width $1.7 \mathrm{~mm}$. Yellowish green. Surface rugose. Body length 12 to $20 \mathrm{~mm}$. All parts of the body above the stigmatal line are pea green. There may or may not be many indistinct pink transverse lines. The whole dorsal area of the body is studded with minute black hairs arising from conspicuous tubercles. The proportion of black to yellowish tubercles varies considerably but in all specimens there are exceptionally large black and occasionally iridescent tubercles just above the stigmatal line. Stigmatal line and spiracles yellow. Substigmatal areas light yellow with yellowish to colorless hairs arising from tubercles of similar color. The hairs on the head arise from the same kind of tubercles.

Fifth Instar

Head height $3.5 \mathrm{~mm}$; head width $3.0 \mathrm{~mm}$. Yellowish green. Covered with many tubercles of the same color from which arise concolorous hairs. Edges of mandibles fuscous. Black pigment of ocelli visible. Body $35 \mathrm{~mm}$. long. Spiracles cream to white in color. Dorsal areas of body clear light 
pea green covered with microscopic blackish hairs arranged more or less in transverse rows on the tops of the transverse folds of each segment. Hairs arise from prominent tubercles. Lemon yellow interrupted suprastigmatal line very thin. Wide stigmatal line whitish green. Below the stigmatal line the body is lighter green. The numerous hairs are longer and more lightly colored. Just dorsal to the stigmatal line is an irregular line of black to iridescent tubercles of various sizes. They are most numerous on the thoracic segments, least numerous on the anal segments. Legs and prolegs light transparent green. Tips of claws on legs slightly fuscous.

\section{Chrysalis}

Length $32 \mathrm{~mm}$. Very light green to yellow. The anterior end terminates in a long thin club-shaped tip. In color this is burnt sienna. From it extend two lateral lines of the same color. Each extends along the dorsal edge of the wing pad then continues as a suprastigmatal line. A middorsal line of similar color passes from the first abdominal segment to the tip of the shallowly bifurcate cremaster. Edges of eyes same color. Body smooth with no prominent hairs or tubercles. The chrysalis is very stout-bodied in the thoracic region bulging considerably ventrally and slightly laterally. It is suspended in the manner characteristic of Pieridæ and Papilionidæ with a girdle around the thorax.

Oviposition is most frequent in the late forenoon and early afternoon. The butterflies circle around large bushes of Cassia spectabilis, deposit a single egg, then another a few feet away. One insect may lay as many as fifteen eggs on a single bush at one visit and repeat the performance at a subsequent visit. Each egg is laid singly on the edge of the leaf. It is fastened by its blunt base but reclines on its side. Eggs laid May 4 hatched four days later on May 8. Each instar requires on the average four days. One larva which pupated May 5 emerged May 14, nine days having passed.

\section{$E g g$}

Nathalis iole Bdv.

Characteristically pierid in shape. Length $.6 \mathrm{~mm}$. Greatest diameter $.27 \mathrm{~mm}$. Longitudinally ribbed. Often as many 
as thirty ribs. The ribs are connected by faint cross stripes approximately $.03 \mathrm{~mm}$. apart. Usually not parallel. The color of the egg at the time of oviposition varies considerably. In one case a freshly laid egg lemon yellow in color was followed fifteen minutes later by one in which the larva was clearly visible through the colorless transparent shell.

First Instar

Head height .2 mm.; head width $.28 \mathrm{~mm}$. Head smooth, shiny black with few short pale hairs. Body length $1.5 \mathrm{~mm}$. deep turtle green. Few long fuscous spatulate hairs scattered over body. Arise from large rounded tubercles. Two para-dorsal, red, fleshy protuberances on prothoracic segment. Each crowned with a rounded shiny black spine.

Second Instar

Head height $.8 \mathrm{~mm}$. head width $.9 \mathrm{~mm}$. Head black to dark brown. Bears many short tapering hairs, colorless to light fuscous. Body length $4 \mathrm{~mm}$. Prothoracic protuberances now bear several short hairs on their sides. Spatulate hairs of body now much shorter. Tubercles from which they arise relatively larger. Each segment now bears in addition to the spatulate hairs a pair of blunt shiny black hairs paradorsally, laterally, and in the suprastigmatal position. All arise from prominent tubercles. Body dark greenish glaucous with dark green mid-dorsal line and light green to white stigmatal line.

Third Instar

Very little change from previous instar. Head light green.

\section{Fourth Instar}

Similar to third instar. Head green to greenish yellow. Fifth Instar

Head height $1.2 \mathrm{~mm}$; head width $1.2 \mathrm{~mm}$. Head light green to yellow. Otherwise not much change. Body length $17 \mathrm{~mm}$. There is a wide variation in the coloring of the larva. The shade of green varies. Some larvæ were grass green while others were dark greenish glaucous. Some possess a darker green mid-dorsal line while others have a bright red 
interrupted line. The stigmatal line ranges from light green to white. Numerous colorless hairs arise from prominent warts. The body is microscopically mottled with the warts arising from dark green areas. Areas between are lighter green. The blunt shiny hairs of the second instar are much reduced and not easily distinguishable from the other hairs of the body. Short fuscous hairs on the head. Head surface finely granular.

\section{Chrysalis}

Length 6.5 to $10.8 \mathrm{~mm}$. Typically pierid-shaped. Dark greenish glaucous. Mottled with light and dark green. Just prior to emergence the dark green mottling assumes a light fuscous appearance. On the wing pads this is in the form of dendritic more or less parallel lines in the same direction as the veins. Those on the tongue case are at right angles to the axis of the tongue. Fewer on abdominal segments; none in intersegmental areas. Absent on dorsal side of abdomen except for an irregular para-dorsal row of splotches. Markings increase laterally and ventrally. Surface smooth. Cremaster blunt. Spiracles rimmed with fuscous. Mouth-parts and especially antennæ are frequently outlined in fuscous.

Eggs were laid May 29 and 31. Some hatched two days later. The duration of the different stages of this species varies extremely. Color markings also show a wide variation. Each instar may require from three days to a week or ten days. The pupal stage requires an average of seven days. Females have never been observed ovipositing earlier than nine o'clock in the morning. Eggs are laid on very small seedlings of Bidens leucantha. Many false starts are made before an egg is actually laid. A female may visit several seedlings and at each one go through the motions of oviposition without extruding an egg. Then she may lay several eggs in rapid succession each on a different seedling.

\section{First Instar}

\section{Eurema lisa (Bdv. \& LeC.)}

Head height $.28 \mathrm{~mm}$. ; head width $.3 \mathrm{~mm}$. Head transparent and nearly colorless. Smooth with few hairs. Length of body $1.7 \mathrm{~mm}$. Transparent yellow. Green in gut visible. Longitudinal rows of rather long fuscous tapering hairs. 
Second Instar

Head height .58 mm.; head width $.6 \mathrm{~mm}$. Head same color. Smooth. Numerous short fuscous hairs over entire surface. Length of body 4 to $5 \mathrm{~mm}$. Same color as before. Mid-dorsal line dark green. Stigmatal line light green. Numerous short black hairs arising from whitish tubercles. Those on anal segment longest.

\section{Third Instar}

Head height $.9 \mathrm{~mm}$. ; head width $1.0 \mathrm{~mm}$. Length of body 5 to $8 \mathrm{~mm}$. Mid-dorsal line Danube green. Para-dorsal line shamrock green. Narrow stigmatal line light turtle green. Remainder of body clear fluorite green. Other characters same as above.

Fourth Instar

Head height $1.4 \mathrm{~mm}$; head width $1.5 \mathrm{~mm}$. Head smooth. Fuscous hairs shorter and more numerous. Length of body 10 to $13 \mathrm{~mm}$. Same as above.

Eggs laid May 31 hatched June 3 three days later. They were laid on the leaves of Mimosa pudica. The female deposited the eggs most often on the top side of the vein of the leaf. She was not disturbed by the action of the plant which closed its leaflets against her abdomen. Upon withdrawal of the abdomen the eggs were hidden from sight.

$E g g$

\section{Papilio celadon Lucas}

Greatest diameter $1.0 \mathrm{~mm}$. Height .9 mm. Light green in color. Nearly spherical. Surface smooth except for a faint reticulation forming microscopic polygonal areas. Food plant not determined.

First Instar

\section{Papilio polydamas L.}

Head height $1 \mathrm{~mm}$; head width $1 \mathrm{~mm}$. Head smooth, chocolate. Few short black hairs. Length of body 3 to $6 \mathrm{~mm}$. Body light chocolate. Covered with minute whitish hairs simulating a pubescence. Larger black hairs on legs, anal segment, and slightly protruding substigmatal areas. Spiracles, legs, and thoracic shield dark chocolate. A row of 
para-dorsal fleshy protuberances. Those on segments one, seven, nine, and twelve, yellow to light orange. Covered with whitish pubescence. Others more darkly colored with chocolate. Prothoracic pair longest.

Second Instar

Head height $1.5 \mathrm{~mm}$.; head width 1.8 to $1.9 \mathrm{~mm}$. Little change from previous instar. Color similar. Fleshy processes longer and brighter yellow. Body length $12 \mathrm{~mm}$.

Third Instar

Head height $2.5 \mathrm{~mm}$; head width 2.8 to $3 \mathrm{~mm}$. Head darker chocolate than preceding instar. Body length $18 \mathrm{~mm}$. Darker chocolate. Processes brighter orange. Those on segments one, two, and three are at the stigmatal line. That on segment four is at the suprastigmatal line; that on segment five, substigmatal. All segments, the first excepted, bear the usual para-dorsal processes. Small pale processes at the bases of all the legs. Those on segments ten and eleven most prominent. All are clothed with microscopic fuscous to black hairs.

Fourth Instar

Head height $3.7 \mathrm{~mm}$; head width $3.9 \mathrm{~mm}$. Head light chocolate early in instar but later becomes shiny black. Body length $22 \mathrm{~mm}$. Dorsal anterior side of prothoracic processes chocolate. Long and tapering. Tips of remaining processes clothed with black hairs. Body chocolate. Dorsal, and to smaller extent, ventral side striped transversely with narrow deep crimson bands.

Fifth Instar

Head height $4 \mathrm{~mm}$. ; head width $4.4 \mathrm{~mm}$. Length of body $27 \mathrm{~mm}$. Similar to preceding instar.

Each instar required from three to five days. The average life cycle required thirty days. Larvæ which hatched May 1 pupated May 21. The pupal stage lasted ten days. As food plant Aristolochia argyreoneuron was preferred, but the following species were eaten to a varying degree: $A$. ringens, $A$. forckelii, $A$. redicula, A. saccata, A. tagala, $A$. fimbriata, $A$. brasiliensis, $A$. cymbifera, $A$. elegans, $A$. gigantea, A. grandiflora, A. glandulosa, A. hians, A. indica, A. Kaempferi, A. Roxburghiana, A. Ruiziana, and A. trilobata. 


\section{Hemiargus filenus Poey}

$E g g$

Pale dull glaucous-blue. Greatest diameter .4 mm. Height $.15 \mathrm{~mm}$. Top surface noticeably concave. Surface with macroscopic polygons formed by a greatly raised reticulation. Polygonal areas further divided into microscopic polygons raised but little above the general surface.

First Instar

Head height $.1 \mathrm{~mm}$.; head width $.15 \mathrm{~mm}$. Head smooth shiny black. Usually retracted. Length of body $.9 \mathrm{~mm}$. Clear light green. Long tapering colorless hairs on body. Para-dorsal and substigmatal rows longest. Hairs usually directed posteriorly.

Eggs laid on Mimosa pudica May 29, 31, and June 1 emerged June 3, 4, and 5. The duration of the egg stage was usually five days. Eggs were laid most frequently at the base of a bud. As with $N$. iole the female made many false starts. An egg would be laid every ten to fifteen trials.

Egg

Pyrgus syrichtus Fabr.

Cream color.

First Instar

Head height $.4 \mathrm{~mm}$; head width $.42 \mathrm{~mm}$. Smooth shiny piceous, with few rather long whitish hairs. Length of body $1.5 \mathrm{~mm}$. Body bears many colorless to fuscous hairs. Those on the prothoracic and anal segments are the longest and of the usual tapering type. Hairs forming the para-dorsal, lateral, and stigmatal lines are branched (Fig. 4). Those below the stigmatal line are of the usual tapering type. Body cream color.

Eggs laid May 22 emerged five days later May 27. Although Sida is listed as the food plant of these larvæ, several local species of Sida were refused by the larvæ which eventually died.

$E g g$

Cabares potrillo (Lucas)

Dark pea green. Greatest diameter $.8 \mathrm{~mm}$. Height .78 $\mathrm{mm}$. Eleven prominent longitudinal ribs. These connected 
by low cross striations (Fig. 7). Eggs failed to hatch. Food plant unknown.

\section{LITERATURE CITED.}

Davenport, D. and Dethier, V. G. 1938. Bibliography of the described life-histories of the Rhopalocera of America north of Mexico 1889-1937. Entomologica Americana, 27 (4) : 155-194.

Ridgway, R. 1920. Color standards and color nomenclature. Washington, D. C.

\section{EXPLANATION OF PLATE III.}

Fig. 1. Second instar head capsule of Calisto herophile Hbn. Approximately $\mathrm{x} 50$.

Fig. 2. Para-dorsal spine of third instar Metamorpha stelenes insularis (Holland). $x 35$.

Fig. 3. First instar head capsule of C. herophile Hbn. $\quad \mathrm{x} 33$.

Fig. 4. Branched hair of first instar Pyrgus syrichtus Fabr. Approximately $\times 200$.

Fig. 5. Egg of C. herophile Hbn. Approximately x 18 .

Fig. 6. Same.

Fig. 7. Micropyle rosette of egg of Cabares potrillo (Lucas). x 35.

Fig. 8. Same as Figs. 5 and 6.

Fig. 9. Diagrammatic representation of the color pattern on an abdominal segment of the third instar larva of $C$. herophile Hbn. Approximately x 16.

Fig. 10. Second instar head capsule of M. stelenes insularis (Holland). $\mathrm{x} 35$.

Fig. 11. Diagrammatic representation of the color pattern on an abdominal segment of the first instar larva of $C$. herophile Hbn. Approximately x 16. 


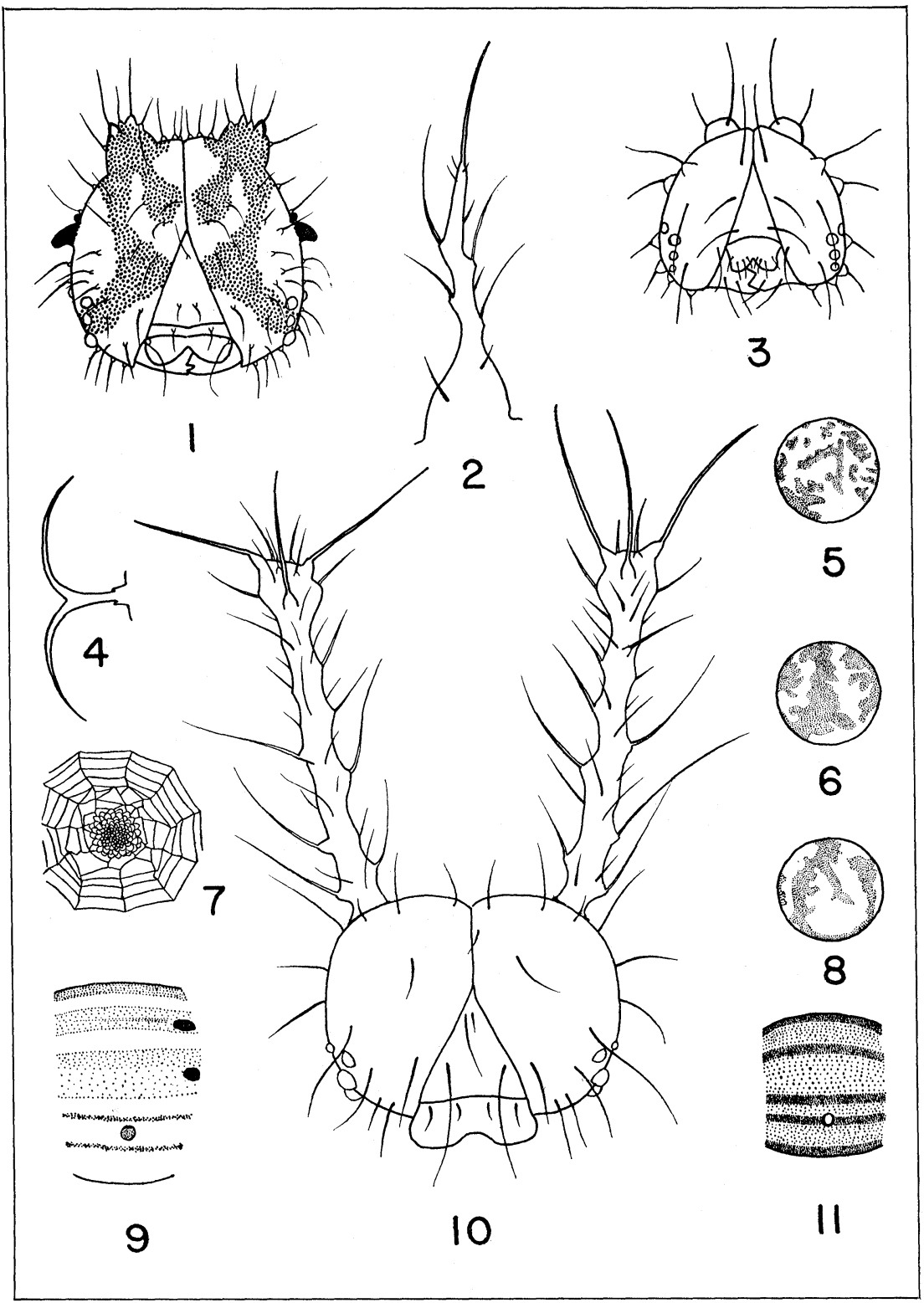

Dethier - Cuban Lepidoptera 

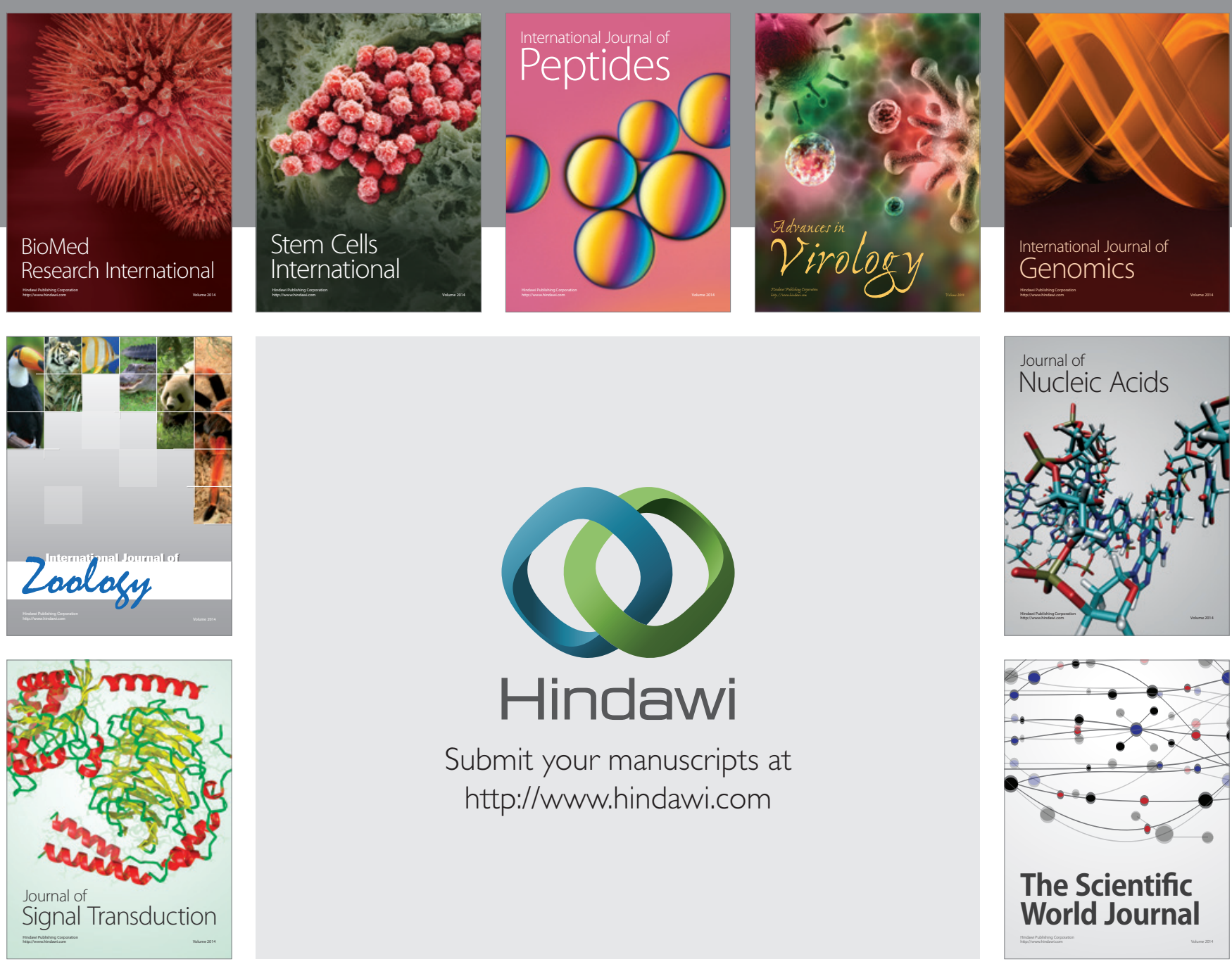

Submit your manuscripts at

http://www.hindawi.com
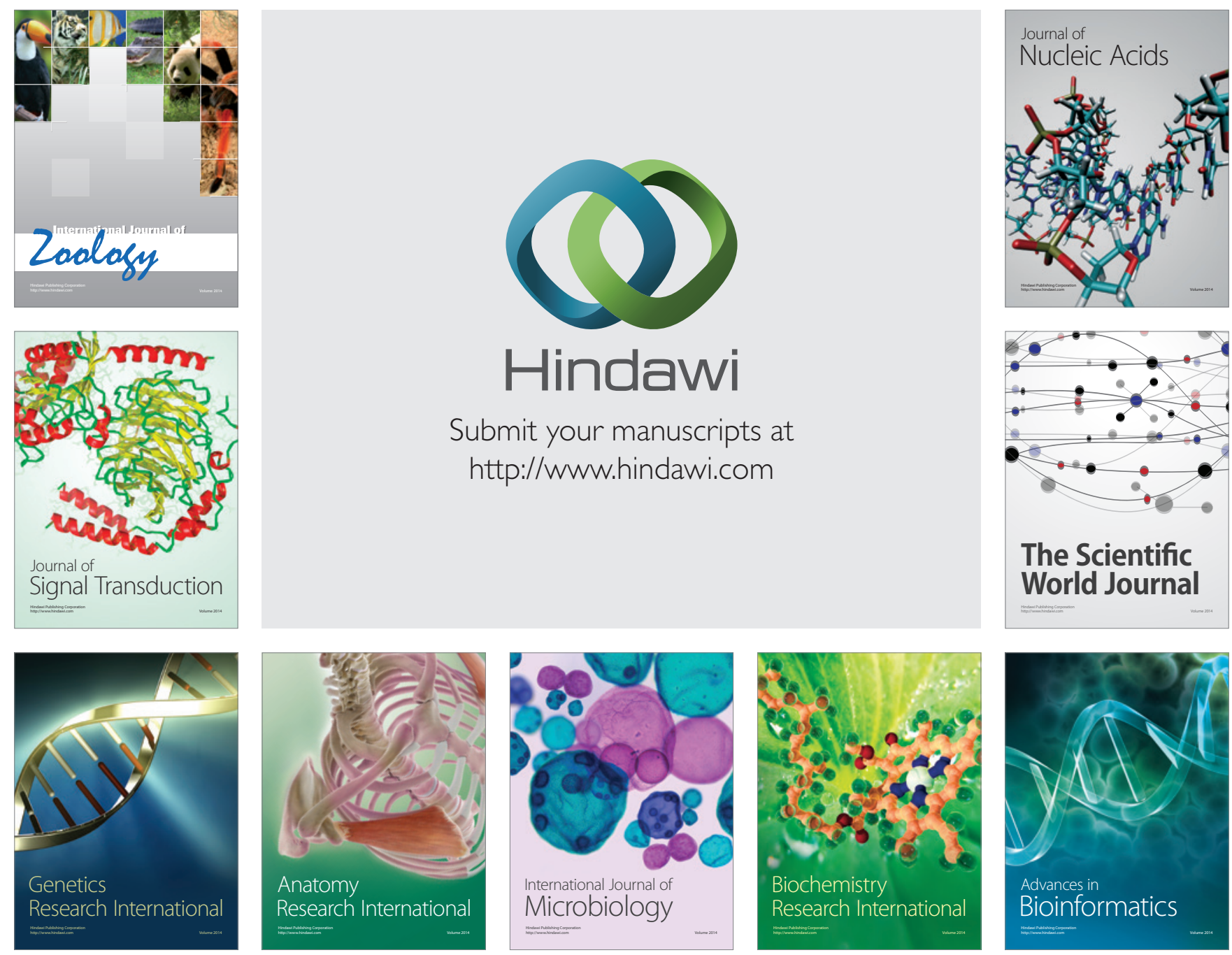

The Scientific World Journal
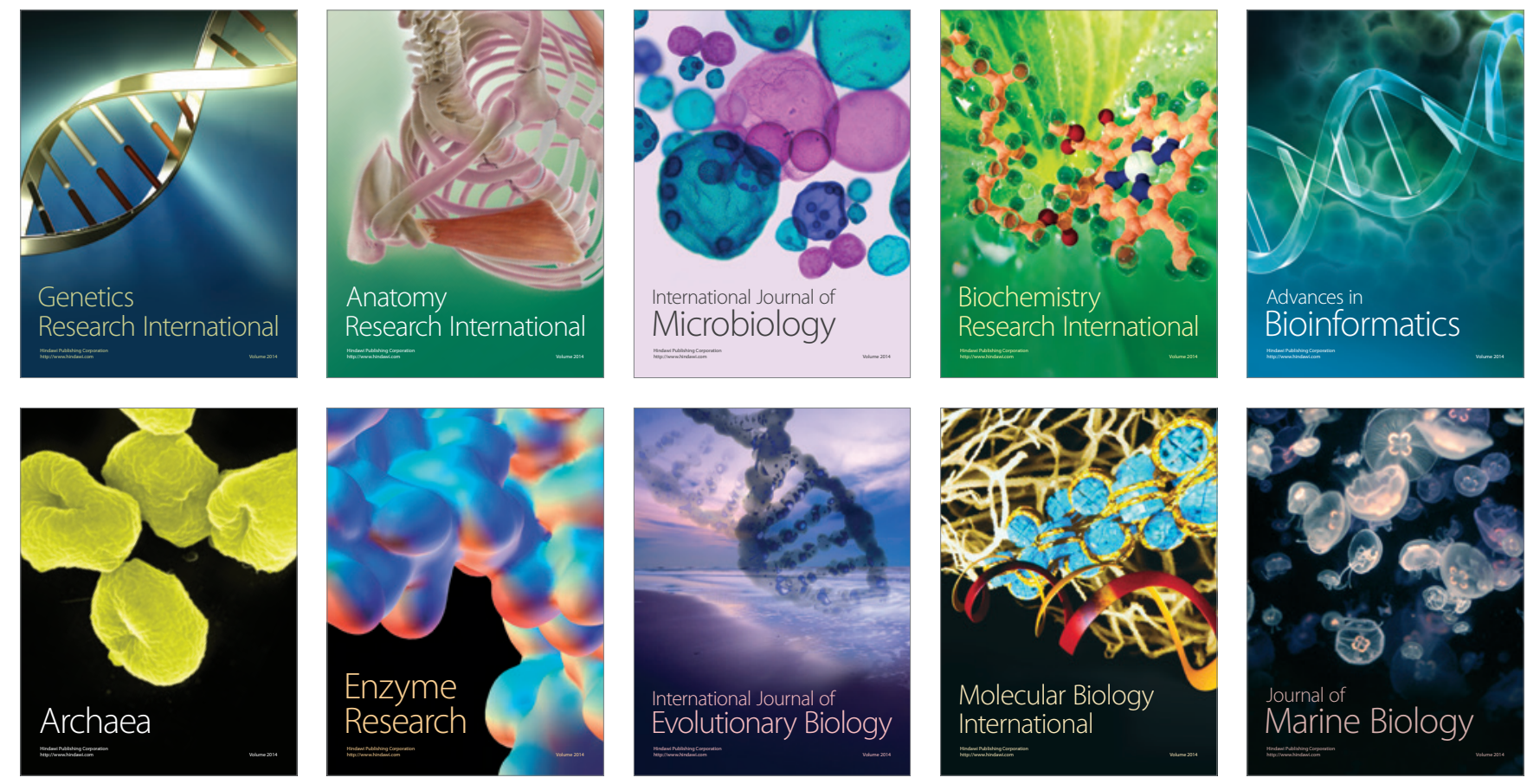